\section{Katarzyna Dąbrowska-Gruszczyńska Marcin Gruszczyński}

(iD) https://orcid.org/0000-0001-7475-2000

Faculty of Economic Sciences University of Warsaw, Poland dabrowska@wne.uw.edu.pl
D https://orcid.org/0000-0002-4755-0785

Faculty of Economic Sciences University of Warsaw, Poland mgruszcz@wne.uw.edu.pl

\title{
Nominal exchange rates EUR/GRD and EUR/ITL in the context of leaving the euro zone by Greece and Italy
}

\author{
Accepted by Editor Ewa Ziemba | Received: October 5, 2020 | Revised: February 9, 2021; \\ March 29, 2021; July 15, 2021 | Accepted: July 16, 2021 | Published: August 27, 2021. \\ (C) 2021 Author(s). This article is licensed under the Creative Commons Attribution-NonCommercial 4.0 license \\ (https://creativecommons.org/licenses/by-nc/4.0/)
}

\begin{abstract}
Aim/purpose - The aim of this paper is to present two cases of crises in Greece and Italy and to evaluate the shadow exchange rates of hypothetical new currencies (re)introduced after Grexit and Italexit.

Design/methodology/approach - Both shadow exchange rates are estimated using speculative pressure index concept that emphasizes the importance of changes in foreign exchange reserves and interest rate differentials in the absence of an independent nominal exchange rate. The research sample covers Greece in 1989-2020 and Italy in 19892020.

Findings - The research presented the estimation of shadow exchange rates EUR/GRD and EUR/ITL during the euro zone membership period. Leaving the euro area one can expect the following market rates: EUR/GRD 600 and EUR/ITL 1850. That would mean $75 \%$ depreciation and 5\% appreciation to the current euro parities EUR/GRD 340.75, and EUR/ITL 1936.27, respectively.

Research implications/limitations - After potential Grexit Greek authorities could expect significant nominal depreciation of a new currency (or should introduce it with a substantial discount). In the case of Italexit, the new currency would preserve its nominal value. The limitations of the research methodology are: a long period of the analysis covers structural changes of financial markets, crisis events, political factors (e.g., QE programs).

Originality/value/contribution - The originality of this approach lies in the combination of two important economic concepts - the idea of shadow exchange rate and the index of speculative pressure. Combined together they help to prepare the methodology

Cite as: Dąbrowska-Gruszczyńska, K., \& Gruszczyński, M. (2021). Nominal exchange rates EUR/GRD and EUR/ITL in the context of leaving the euro zone by Greece and Italy. Journal of Economics \& Management, 43, 293-316. https://doi.org/10.22367/jem.2021.43.14
\end{abstract}


of shadow exchange rates evaluation for currencies that are currently in the common currency system (e.g., currency union). These results can help in economic and political discussions on effects of leaving the currency union.

Keywords: nominal exchange rates, euro area, financial crises.

JEL Classification: F21, F31, F37, F38, G15.

\section{Introduction}

Over the past ten years the European Union has experienced many political and economic shocks, both internal and external. In the external environment the most important risk factor was the global rivalry between China and the United States (Goulard, 2020). Internal crises included Brexit, the debt crisis, the migration crisis, and more recently the COVID-19 crisis (Ehnts \& Paetz, 2021; Frieden \& Walter, 2017). Problems with rising public debt and fiscal stability of Greece and Italy also facilitated discussions about the future of the euro zone and possibility of introduction of south and north currencies in the euro area (Scharpf, 2017) or re-introduction of national currencies (Thanki, 2015). Potential exit of some countries from the common currency area also means the question of new exchange rates of new currencies against the euro.

The aim of this study is to evaluate the nominal shadow exchange rate of Greek drachma (GRD) and Italian lira (ITL) against the euro in the case of their sudden withdrawal from the euro zone. It is expected that such a move will result in sharp depreciation of new currencies due to heavy debt burden, economic deformations, potential banking crises and negative shifts of investors' sentiments (Bagnai, Granville, \& Mongeau Ospina, 2017).

The research hypothesis is that Grexit and Italexit should lead to sudden and sharp nominal depreciation of new currencies. The scale of the depreciation should be predicted and confirmed by a substantial difference between the current euro parity and the shadow exchange rate estimated in this research. ${ }^{1}$

The economic literature usually takes into account real exchange rates and potential trade effects (Couharde, Delatte, Grekou, Mignon, \& Morvillier, 2017). In our opinion nominal rates can bring also some financial market-oriented in-

1 Frankel \& Rose (1996) define a currency 'crash' as a nominal, annual depreciation of the currency of at least 25 percent that is also at least a 10 percent increase in the annual rate of depreciation. A crisis or currency crash is also defined to occur if the monthly depreciation exceeds 10 percent and also exceeds the monthly average depreciation months prior to the crisis plus twice the standard deviation of the rate of depreciation over the preceding two years (Osband \& Van Rijckeghem, 2000). 
formation and help to understand either current disparities or the size of potential currency crash.

In the next section of the paper we describe political and economic environment of Grexit and Italexit to show the importance of the problem, both in economic matters and in political management.

In section three we present two academic concepts that helped us to estimate nominal exchange rates EUR/GRD and EUR/ITL in the case of leaving the euro zone. These are the concepts of shadow exchange rate (Piersanti, 2012) and the index of speculative pressure (Eichengreen, Rose, \& Wyplosz, 1994). This index is currently widely used and developed in various studies (Kaminsky, 2006; Ural \& Balaylar, 2007) but is employed for estimation of shadow exchange rates for a first time.

In the fourth section we describe methodological background of our survey. In section five we present results, either behavior of index of speculative pressure or nominal exchange rates EUR/GRD and EUR/ITL during the period of staying by Greece and Italy in the euro area. In the last, sixth section we discuss critically our findings.

\section{Literature review on prospects of Grexit and Italexit for new currencies}

A common currency, apart from the obvious benefits, entails certain costs, especially political ones. In the last decade, two important European countries considered leaving the euro area and the re-introduction of national currencies. Key issues in these cases were new exchange rates of these currencies.

\subsection{Greece}

The first speculations about a possible exit from the monetary union by a member of the euro zone emerged in 2010, although the expression' Grexit' leaving the euro zone by Greece - first appeared in February 2012 (Buiter \& Rahbari, 2012).

At the turn of 2010 and 2011, two possible scenarios for Greece, struggling with severe financial problems, were considered. The first was the declaration of bankruptcy by Greece. There appeared several objections about negative consequences of such a step: immediate limitation of the use of Greek financial instruments in money market transactions, the urgent need to improve the budget 
balance in the short term, the loss of confidence in Greece, a significant reduction or even suspension of transfers of international funds to Greek enterprises (or an increase in the cost of obtaining them). Nevertheless, a declaration of insolvency at that time, would open up some new possibilities for the Greek government.

At the same time, a second, alternative scenario was considered. It was the forced (or voluntary) leave of the euro area by Greece (i.e., Grexit). However, the provisions of the Lisbon Treaty (Article 50) do not provide the possibility of exclusion (by force or voluntarily) a country from the euro area while maintaining the status of an EU Member State (Athanassiou, 2009). The discussions highlighted both the benefits and risks of this move. The arguments in favor of leaving the euro area included regaining, at least partially, autonomy (sovereignty) of economic and fiscal policy (Thanki, 2015). The devaluation of the new currency (estimated at up to 30-50\%) should help to restore competitiveness and reduce the current account deficit. Grexit would enable an independent monetary policy. Moreover, staying in the euro zone would help nothing for Greece. Austerity policy, undercutting long-term growth, would fuel social unrest, and debt would continue to rise. Positive example at the time was Iceland, which recorded strong economic growth despite the banking crisis and a large depreciation of the national currency.

The objections were raised about the possibility of a potential capital flight from Greece in the face of leaving the Euro zone, loss of credibility and problems in future borrowing. Exiting the euro area would mean a sharp increase in transaction costs and hedging. Another problems would be converting deposits and loans (e.g., mortgage loans) and behavior of the new exchange rate. If it were considered too high by market participants, one could expect an outflow of capital to other countries where deposits are better guaranteed, or even a bank run because of fears of devaluation. If it were too low, there could appear pressure from trade unions to increase nominal wages to compensate the loss of purchasing power (BBC, 2015).

It should also be noted that the authorities could increase the money supply and pay off debts in new local currency but it could cause a serious inflationary pressure. Furthermore, the benefits of devaluation could be offset by the increase in import costs (of machines, cars, crude oil, chemical products, food), mainly from euro area countries.

More arguments were presented by Provopoulos (2010), president of the Bank of Greece. Public debt would turn into foreign debt, which would automatically burden the country. Imported prices would rise, leading to inflation and 
lower living standards. Without the ability to cooperate with the ECB, monetary policy would be less credible, fueling inflationary expectations. Provopoulos (2010) also emphasized the lack of economies of scale to be seized. Increased uncertainty about the exchange rate would make doing business more difficult, and an increase in nominal interest rates would shift reserves from manufacturing sectors to asset markets. Growing currency risk would lead to a further devaluation of 50\% (Wolinsky, 2011).

There could also emerge some problems for the European Union. Grexit could easily hit other European member states at the same time and subsequently affect the entire euro zone. Investors' confidence could be undermined very badly also in Spanish, Italian, and Portuguese markets. It could also increase probabilities of sovereign defaults and further recessions. Analysts believed that the euro had been able to follow a similar trend if Greece eventually left the euro zone, taking a momentary dip and recovering. The move could also have later impacts if investors turned their attention to other, possibly vulnerable, members of the euro zone, such as Spain and Italy, both of which have also struggled with heavy debt loads (Shor, 2015).

At the same time, there appeared proposals to create a dual-currency system in the euro area, consisting of the northern euro and the southern euro. The northern euro would apply in stable 'north' countries (with balanced budgets), the weaker, 'southern' euro - in countries requiring improvement of competitiveness using such an unconventional method.

Proponents of this plan expected that the southern euro countries would be able to increase their international competitiveness, and thus exports, through devaluation. However, more expensive imports would stabilize the trade balance. For northern countries (mainly Germany), this situation would not be unfavorable, because Germany had a colossal export surplus (Mayer, 2012).

In May 2010, Greece received EUR 110 billion of aid from the European Union and the International Monetary Fund and committed to reform under their supervision. On October 27, 2011, the debt to banks was reduced by 50\% (EUR 107 billion). In March 2012, Greece received EUR 130 billion under the second aid program of the ESFS and the IMF. The reduction rate increased to $53.5 \%$, after replacement of Treasury bonds with new ones and extending their maturity from 15 to 30 years. Thanks to the austerity program, the budget deficit was reduced from $16 \%$ to $8 \%$ of GDP in 2009-2012 and the primary deficit from $10 \%$ to $1 \%$. 
Next concerns about the possibility of Grexit emerged in May 2015 and they were fueled by the negotiations of Greek authorities to obtain further funds and the simultaneous social referendum on the acceptance of the terms of expected agreement. The next, third aid program was conditioned on the pension reform, the appropriate fiscal strategy and the launch of a privatization fund of EUR 50 billion.

In addition to economic criteria, political conditions were also set. They included the verification of the state budget for 2018, a social welfare revision, labor market reform, public administration issues and implementation of the Non-Performing Loans strategy, energy sector reforms and privatization.

In December 2017, the Greek government agreed to further spending and pensions cuts, to finish the qualification review of public sector workers and to sell coal power plants. June 21, 2018, the Eurogroup positively assessed the reforms carried out and macroeconomic results achieved (general government deficit, GDP growth; Figure 1) and agreed on the assumptions for the completion of the third aid program - which was regarded as the end of the Greek crisis.

Figure 1. Budget balance (in \% of GDP) and real GDP growth (in \%) in Greece in 2009-2019

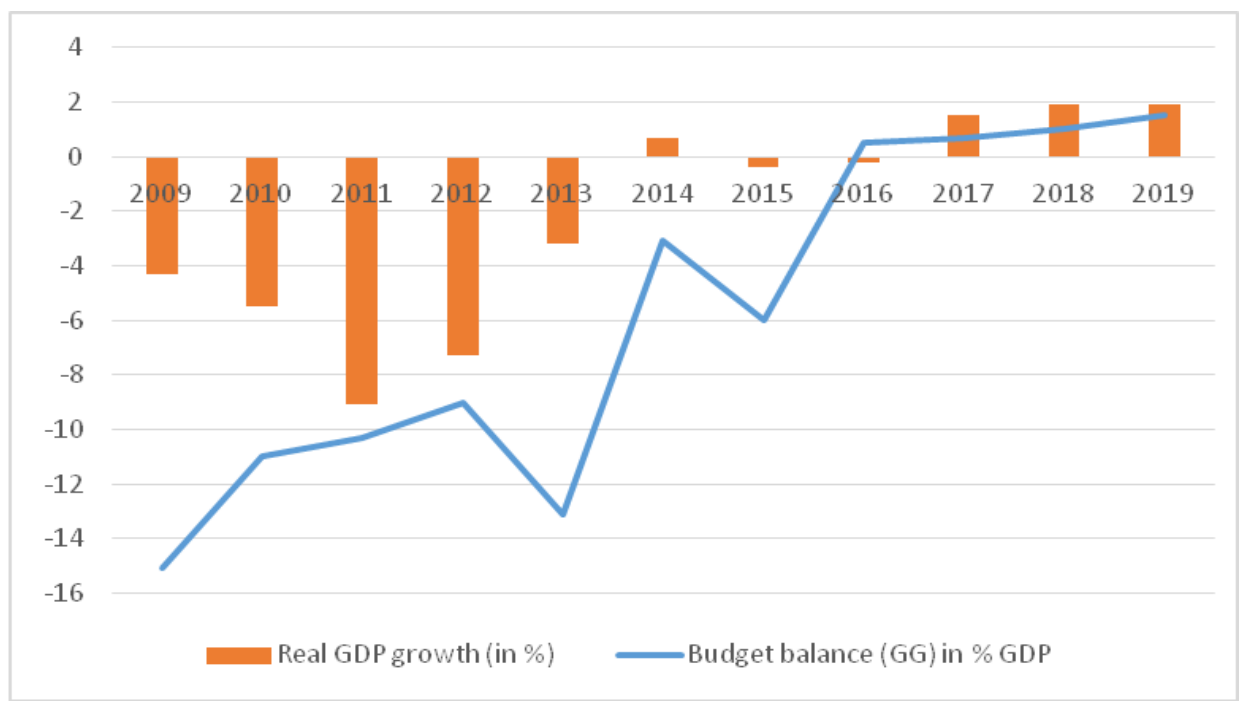

Source: Eurostat (2020abc).

The end of the program means that Greece will be no longer formally bound to strict conditions of financial discipline and economic reforms. The government will be able to issue debt securities and sell them on the financial 
markets. So far, Greece has received EUR 288.7 billion under aid programs (EUR 256.6 billion from the EU and EUR 32.1 billion from the IMF). To pay off the debt towards EU partners, it should generate a primary surplus in the budget for the next 42 years.

Parallel to the struggle to keep Greece in the euro zone, there was a discussion about the potential effects of leaving the common currency area. Mariolis (2013) suggests that a return to national currency would not necessarily deepen the recession, although a rather large nominal devaluation, i.e., in excess of $57-60 \%$, is necessary for the recovery. Katsinos \& Mariolis (2012) estimated the effects of a switch to devalued drachma on the cost-inflation rate in the Greek economy and stated that inflationary 'pressures' (expected after Grexit) would be not too high and, therefore, there would be room for trade-balance improvement.

\subsection{Italy}

Italy is one of the oldest members of the European Union, an industrialized country and one of the most indebted members of the euro area. The persistence of excessive debt seems to be caused by the political instability and ineffectiveness of the Italian state organization system (Cepiku, 2018; Di Quirico, 2010). The problem of indebtness is a common concern due to the possible repercussions of potential state insolvency, malfunctions of poorly capitalized banks, which would have serious political and financial consequences for the European Union (e.g., an increase in risk premiums for European securities).

Italexit question (Italeave or Quitaly) was discussed twice. For the first time during the campaign before the Constitutional Referendum on December 4, 2016, and for the second time - during the campaign before and after the parliamentary elections in 2018. It is worth noting that Italy does not consider leaving the European Union, and Italexit rather means 'just' leaving the euro zone.

In 2016, the government of Prime Minister Renzi made an attempt of systemic changes in Italy. They were aimed at streamlining the legislative process and improving the efficiency of state management. Concerns about the result of the referendum pushed the risk premium up from $1.06 \%$ in August to $2.1 \%$ in November 2016. The uncertainty also spilled over to bond markets of other euro area countries, e.g., the yield on German bonds jumped from $-0.12 \%$ to $0.38 \%$ in the same period. The European Central Bank announced that it would be ready to increase the purchase of Italian bonds, if the debt servicing costs increased drastically, threatening financial stability of Italy. This operation was designed to last a few days only and was limited to EUR 80 billion (Gavin, 2017). 
There were also concerns that after Prime Minister Renzi's possible resignation, the elections could be won by the Five Star Movement (announcing the exit from the euro zone and the European Union), which would stop public aid for eight Italian banks.

It is worth noting that former prime minister Berlusconi, criticizing the Renzi project at the same time, opted for a dual currency system in Italy. He stated that "the euro was a poorly conceived project and did not produce good results for Italy or Europe." He proposed a dual-currency system that "partially reflects our sovereignty over the currency without leaving the circle of the euro" (Die Welt, 2016 ). This concept corresponded with the idea (proposed in 2010) to introduce the northern and southern euro (Scharpf, 2017).

For the second time, controversies about leaving the EU and the euro zone appeared at the end of 2018 and in the first half of 2019. Compared to 2016, there was a major change in Italian politics. The government was formed by Salvini League and Di Maio Five Star Movement. Serious concerns were caused by the draft budget for 2019, which provided for an increase in budget spending and cuts in taxes. This meant that public debt of Italy would continue to rise. There were also reports that the program points of the agreement between these two parties included the demand for the cancellation of Italy's debt to the ECB amounting to EUR 250 billion and the withdrawal from the euro area.

In June 2019, the European Commission proposed the opening of an Excessive Deficit Procedure (EDP) for Italy's lack of compliance with the debt criterion. The state subject to the procedure should follow the recommendations of the EU Council, under the penalty of an interest-free deposit of an amount corresponding to $0.2 \%$ of GDP (in the case of Italy, it would be approx. EUR 3 billion). The possibility of such a high penalty fueled further considerations about Italexit.

The problem of Italexit is present in the scientific literature. Bagnai et al. (2017) simulate the impact of withdrawal from the euro area on the Italian economy. They predict banking crisis, and suggest that realignment of the nominal exchange rate would not bring about any statistically significant benefit in terms of growth in the medium run. However, it would open some fiscal space. Supplemented with an expansionary policy stance, the realignment would contribute to a significant increase in output and employment, and hence to effective fiscal consolidation (Bagnai et al., 2017, p. 533).

Recent events have brought proposals of cancelling sovereign bonds bought during the pandemic or perpetually extending their maturity. The reaction of the EU authorities was negative (Martin, 2020). 


\section{Literature review on shadow exchange rates and index of speculative pressure}

In this part, the authors would like to introduce a concept of shadow exchange rate. The shadow exchange rate is widely used in the context of international trade (Medalla \& Power, 1984; Tsakok, 1990), economic analysis of foreign projects or programs (Lagman-Martin, 2004) and finance (Piersanti, 2012), especially in the absence of free market exchange rates. In the last case, the shadow exchange rate helps either to estimate the actual purchasing power or to determine the exchange rate that would prevail in the market after removal of exchange rate controls. The shadow exchange rate is commonly used when the official exchange rate is under control (fixed, pegged) or when the rate is determined generally by market forces but there are significant capital restrictions on transactions in the market.

Flood \& Garber (1984) defined shadow exchange rate as the floating exchange rate after a collapse of the fixed-rate regime. This rate would appear in the market after the traders bought out all remaining foreign reserves used to defend the peg, and the central bank refrained from foreign market interventions thereafter. In Krugman (1979) model the shadow rate balances the money market after foreign reserves have been run out. Marion \& Flood (1998) defined the shadow exchange rate (ser) during the period of control as:

$$
\operatorname{ser}=\alpha \mu+\mathrm{d}
$$

where:

$\mathrm{d}$ - domestic credit,

$\mu$ - rate of growth of domestic credit,

$\alpha$-elasticity of shadow exchange rate for the rate of growth of domestic credit.

They suggested that $\mu$ is equal to the drop rate of foreign exchange reserves.

In this paper the authors decided to combine the concept of shadow exchange rate with the idea of an index of speculative pressure. This index was developed by Eichengreen et al. (1994). They suggested that the pressure on a currency can not only result in a sharp depreciation, but it can also be accompanied by a drop of foreign exchange reserves and by a sharp growth of interest rate differential. Central banks can defend desired parity using either foreign reserves or short interest rates, or both of them. Eichengreen et al. (1994) idea started with a textbook money demand function. Girton \& Roper (1977) speci- 
fied the percentage change in base money $h$ as a function of the percentage change in the price level $p$, the percentage change in real income $y$ and the percentage change in interest rates $i$. Since base money is the sum of domestic credit $D$ and international reserves $R$, Eichengreen et al. (1994) defined $r=E R / H$ and $d=D / H$, where $E$ is the domestic price of a unit of foreign exchange. Thus,

$$
\left(r-r^{*}\right)+\left(d-d^{*}\right)=\left(p-p^{*}\right)+\beta\left(y-y^{*}\right)-\alpha\left(i-i^{*}\right)
$$

where:

$\alpha$ - interest-rate semi elasticity for money demand,

$\beta$ - income elasticity for money demand, asterisks denote the foreign country.

Using purchasing power parity to substitute the rate of depreciation for the inflation differential, and rearranging terms, Eichengreen et al. (1994) derived:

$$
e+\left(i-i^{*}\right)-\left(r-r^{*}\right)=\left(d-d^{*}\right)-\beta\left(y-y^{*}\right)+(1+\alpha)\left(i-i^{*}\right)
$$

The left-hand side of the equation (2) is the index of speculative pressure, which says that pressure increases as domestic reserves of foreign exchange decline, as domestic interest rates rise and as the exchange rate depreciates (e, the log of the exchange rate, rises). Theoretical underpinnings suggest that speculative pressure should be a parametric function of fundamentals, such as the rate of growth of domestic credit, the level of income, and the interest rate differential (Eichengreen et al., 1994, p. 15).

Eichengreen et al. (1994) prepared their own index of speculative pressure (ISP) as follows:

$$
\mathrm{ISP}=\% \Delta \mathrm{e}+7\left[\% \Delta\left(\mathrm{i}-\mathrm{i}^{*}\right)\right]-0.08\left[\% \Delta\left(\mathrm{r}-\mathrm{r}^{*}\right)\right]
$$

where:

$e$ - the price of a Deutsche Mark (German currency before the euro),

$i$ - the short interest rate,

$r$-the level of international reserves, and an asterisk denotes German variables.

The components of their index were weighted to equalize volatilities. ${ }^{2}$ The interest rate differential variable was transformed by taking differences between domestic and foreign (German) annualized first-differences of natural logarithms (Eichengreen et al., 1994, p. 17). Eichengreen et al. (1994) used their index to identify periods of significant (measured in terms of value of the index greater than 1.5 of standard deviations above the sample mean) speculative pressures

2 An intuitive if arbitrary approach is therefore to weight the three components of the index so that their conditional volatilities are equal (Eichengreen et al., 1994, p. 16). 
during attacks on pegged exchange rates in 22 countries in 1967-1992 (with a special interest in seven members of Exchange Rate Mechanism).

This stimulating idea brought many interesting applications, such as Index of Currency Market Turbulence (Kaminsky, 2006), Banking Sector Fragility Index (Kibritçioğlu, 2002) and Excessive Risk Index (Ural \& Balaylar, 2007).

\section{Research methodology}

In this part we would like to analyze the behavior of the EUR/GRD and EUR/ITL shadow exchange rates during the period of staying in the euro area. These rates will be obtained by decomposing speculative pressures (in respect to exchange rate) estimated by the speculative pressures index for the common currency period, but using the weights obtained from the preceding period (before the introduction of common currency in Greece and Italy).

Two changes were introduced to the original concept of Eichengreen et al. (1994). First, it was decided not to take into account the relevant foreign exchange reserves. What was possible in the short term in the first half of the 1990s (taking Bundesbank reserves) is extremely difficult in a study covering years 1989 to 2020 . While the issue of the euro exchange rate in the period up to 1989 or national foreign reserves could be resolved, we cannot solve the problem of a proper simulation of the euro area foreign exchange reserves in the run-up to 1999. In 1989-1999 there were too many crucial systemic changes (for example, the rules and functioning of the European Monetary System, the rules, functioning and changes of the Exchange Rate Mechanism) to propose a good approximation of reserves of the non-existed yet euro area. Adding up the foreign exchange reserves of future member states would be ahistorical. They were obliged to cooperate, but to defend the system, not the currency.

Another problem is the two-tier system of managing foreign exchange reserves in the euro area. This means the decision-making dependence of the euro zone member states. They are responsible for both the stability of the euro and the level of national foreign exchange reserves (and those transferred to the European Central Bank). Moreover, according to Art. 30 of the ECB Statute, ECB may, if necessary, request additional contributions from national central banks, on demand of the ECB's Governing Board. This means that the national foreign exchange reserves are in principle at the disposal of the ECB. It was also unjustified to use the Bundesbank reserves only, as in Eichengreen et al. (1994). 
Second, the methodology of estimating the Speculative Pressure Index (presented in the previous section) has been simplified. The values of the speculative pressure index are calculated using monthly percentage changes of selected components, and, similarly to Eichengreen et al. (1994) concept, weighted to equalize volatilities.

The study presented in this paper was carried out in three stages.

Stage one. In step one we evaluated speculative pressure indexes for 'national currency' period (floating, uncontrolled rate) for GRD and ITL.

Step 1: $\operatorname{ISP}(1)=\boldsymbol{\alpha}_{1} \% \Delta \mathrm{e}+\boldsymbol{\beta}_{1}\left[\% \Delta\left(\mathrm{i}-\mathrm{i}^{*}\right)\right]-\boldsymbol{\gamma}_{1}[\% \Delta(\mathrm{r})]$

In step two, we calculated values of these indexes for 'euro currency' period (membership in the euro zone).

Step 2: $\boldsymbol{I S P}(\mathbf{2})=\boldsymbol{\beta}_{2}\left[\% \Delta\left(\mathrm{i}-\mathrm{i}^{*}\right)\right]-\boldsymbol{\gamma}_{\mathbf{2}}[\% \Delta(\mathrm{r})]$

In step two, the exchange rate component is missing, because there are no national currencies anymore. The only components representing pressure on domestic financial market are interest rate differentials and foreign reserves.

Stage two. In stage two, we decomposed 'euro currency' indexes (with respect to (shadow) exchange rate) but using the weights from the "national currency' ones.

Step 3: $\% \Delta \operatorname{ser}=\left\{\mathbf{I S P}(2)-\boldsymbol{\beta}_{1}\left[\% \Delta\left(\mathrm{i}-\mathrm{i}^{*}\right)\right]+\boldsymbol{\gamma}_{\mathbf{1}}[\% \Delta(\mathrm{r})]\right\} / \boldsymbol{\alpha}_{\mathbf{1}}$

We used weights from the first period and applied to the second period but with the values of speculative pressure from the second period.

Stage three. Estimation of shadow exchange rates (ser) using initial fixing exchange rates (EUR/GRD 340.75, and EUR/ITL 1936.27) and subsequent monthly changes obtained in the second stage ( $\% \Delta$ ser).

All data used in this research were obtained from the International Monetary Fund (IMF, 2018; 2020), additional, specific data were taken from the Bank of Greece (www.bankofgreece.gr) and the Bank of Italy (www.bancaditalia.it). We used monthly frequency $(\mathrm{M})$ of data. For Greece: nominal rate EUR/GRD (174..EB.ZF..., Exchange Rates, Domestic Currency per ECU, Period Average, Rate; Exchange Rates, Domestic Currency per Euro, Period Average, Rate), foreign exchange reserves (174.1L.DZF..., International Reserves and Liquidity, Liquidity, Total Reserves excluding Gold), ${ }^{3}$ interest rates: (17460C..ZF...; Treasury Bill Rate-12 Months); foreign - Germany: interest rates:

\footnotetext{
We added to this component foreign reserves held in European System of Central Banks (see chapters "Liabilities equivalent to the transfer of Foreign reserves" in annual reports and annual accounts of European Central Bank (2019ab). Theoretically, in the case of Grexit or Italexit, they can be withdrawn from ECB and used for defending national currency.
} 
(13460B..ZF...; Money Market Rate). For Italy: nominal rate EUR/ITL (136..EB.ZF...; Exchange Rates, Domestic Currency per ECU, Period Average, Rate; Exchange Rates, Domestic Currency per Euro, Period Average, Rate), foreign exchange reserves (136.1L.DZF...; International Reserves and Liquidity, Liquidity, Total Reserves excluding Gold), interest rates: Italian (13660C..ZF...; Treasury Bill Rate) and foreign - Germany -(13460B..ZF...; Money Market Rate).

\section{Research results and findings}

Using the methodology described in the previous section, the following ISP formulas for 'national currency' periods were obtained:

Greece, January 1989 - December 2000

ISP $($ GRD period $)=(0.0133) \Delta \mathrm{e}_{\mathrm{t}}+(0.0356)\left[\Delta\left(\mathrm{i}-\mathrm{i}^{*}\right)_{\mathrm{t}}\right]-(0.1342)\left[\Delta(\mathrm{r})_{\mathrm{t}}\right]$

Italy, January 1989 - December 1998

$\operatorname{ISP}(\operatorname{ITL}$ period $)=(0.0185) \Delta \mathrm{e}_{\mathrm{t}}+(0.098584)\left[\Delta\left(\mathrm{i}-\mathrm{i}^{*}\right)_{\mathrm{t}}\right]-(0.0905)\left[\Delta(\mathrm{r})_{\mathrm{t}}\right]$

In Figure 2, we can see the Index of Speculative Pressure on Greek drachma during 'national currency' period. The picture is quite surprising, the common perception of GRD as a currency was rather weak, but speculative pressure in 1989-2000 was rather uncommon and limited. In the eve of the euro adoption the Greek drachma experienced rather positive, long lasting market pressure leading to the accumulation of foreign exchange reserves and a decline in risk premium.

In Figure 3, we can analyze the Index of Speculative Pressure on the Italian lira during 'national currency' period. We can distinguish two big speculative attacks (over 1.5 standard deviations above the sample mean) on the Italian lira in 1992 and 1994/95 that ultimately led to the exit of the lira from Exchange Rate Mechanism. 
Figure 2. Index of speculative pressure on GRD; Greece 1989-2000

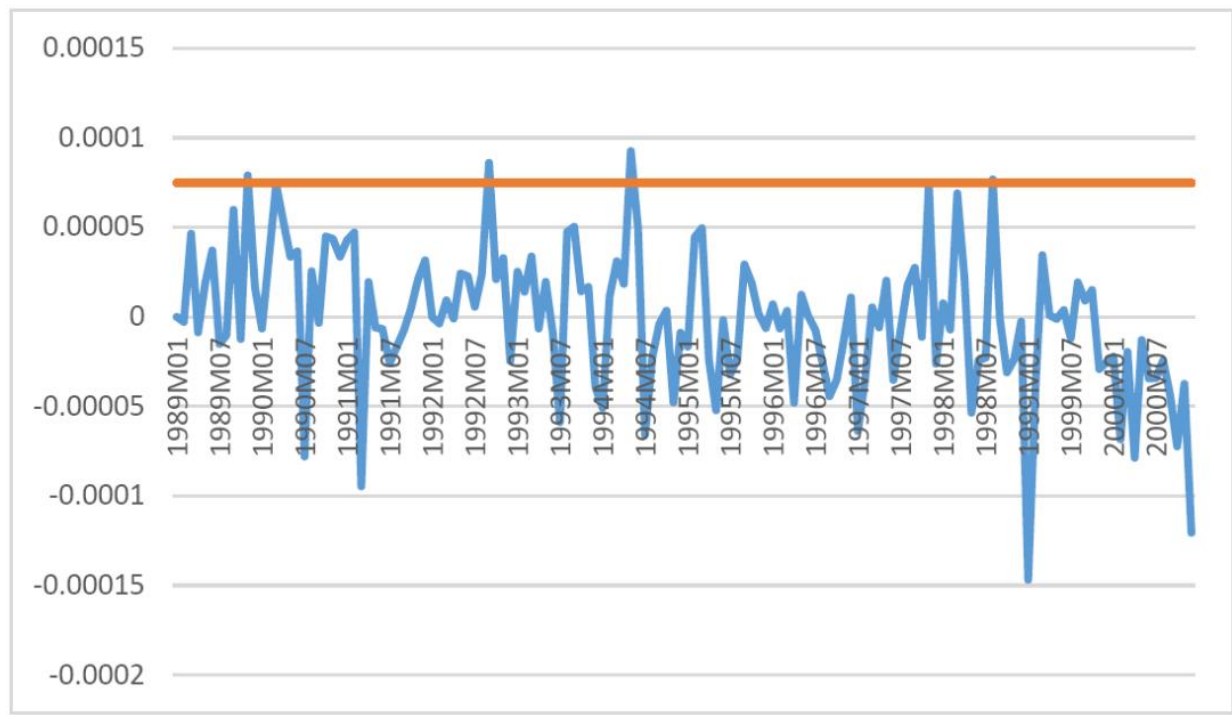

Note: Orange horizontal line is 1.5 standard deviation crisis threshold level.

Source: Authors' own calculations.

Figure 3. Index of speculative pressure on ITL; Italy 1989-1998

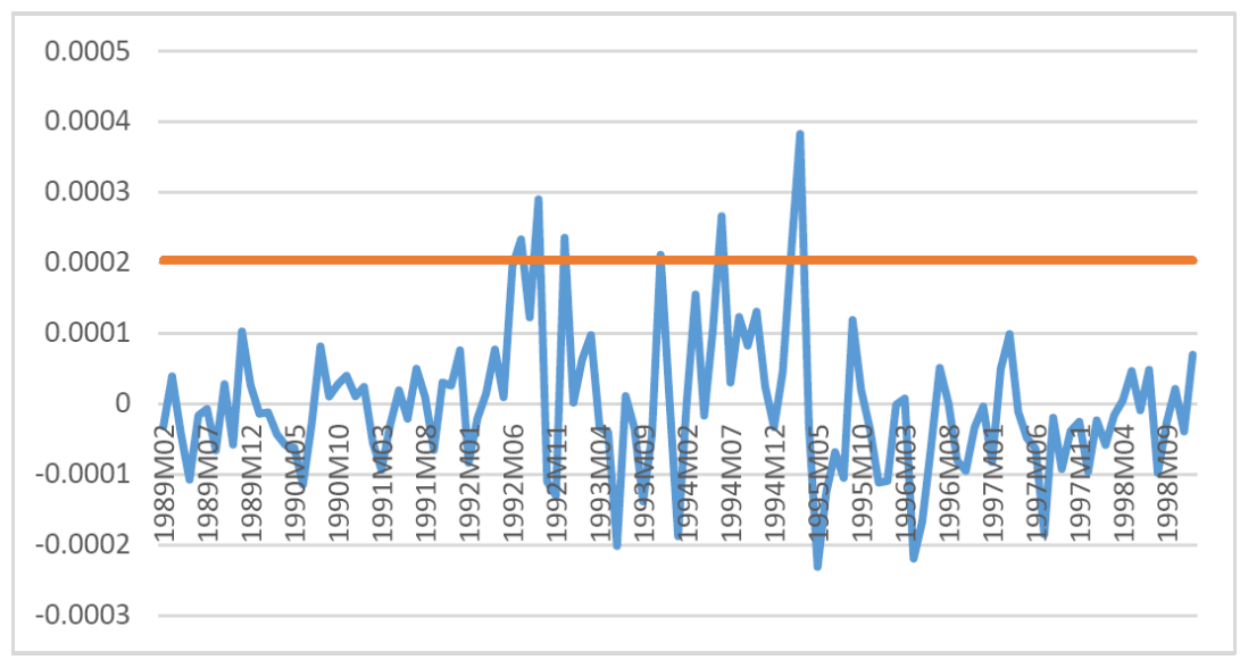

Note: Orange horizontal line is 1.5 standard deviation crisis threshold level.

Source: Authors' own calculations. 
In the next step, we estimated speculative pressure index formulas for "euro membership" periods:

Greece, January 2001 - May 2020

ISP $($ euro membership $)=(0.1541)\left[\Delta\left(\mathrm{i}-\mathrm{i}^{*}\right)_{\mathrm{t}}\right]-(0.0925)\left[\Delta(\mathrm{r})_{\mathrm{t}}\right]$

Italy, January 1999 - June 2020

ISP $($ euro membership $)=(0.1687)\left[\Delta\left(\mathrm{i}-\mathrm{i}^{*}\right)_{\mathrm{t}}\right]-(0.0405)\left[\Delta(\mathrm{r})_{\mathrm{t}}\right]$

In Figure 4, we can see that significant pressure was present in the Greek market in 2003-2004. Some speculative attacks occurred in 2008 and 2010. Our attention can be attracted by the sudden, extraordinary appreciation pressure in August 2009. This phenomenon can be explained by a sudden growth of foreign reserves from USD 367.5 million in July to USD 1.34 billion one month later. Another interesting, crisis event, occurred in March 2020 with a sudden growth of Greek interest rates (from $1.07 \%$ in February to $1.97 \%$ month later).

Figure 4. Index of speculative pressure on GRD; Greece 2001-2020

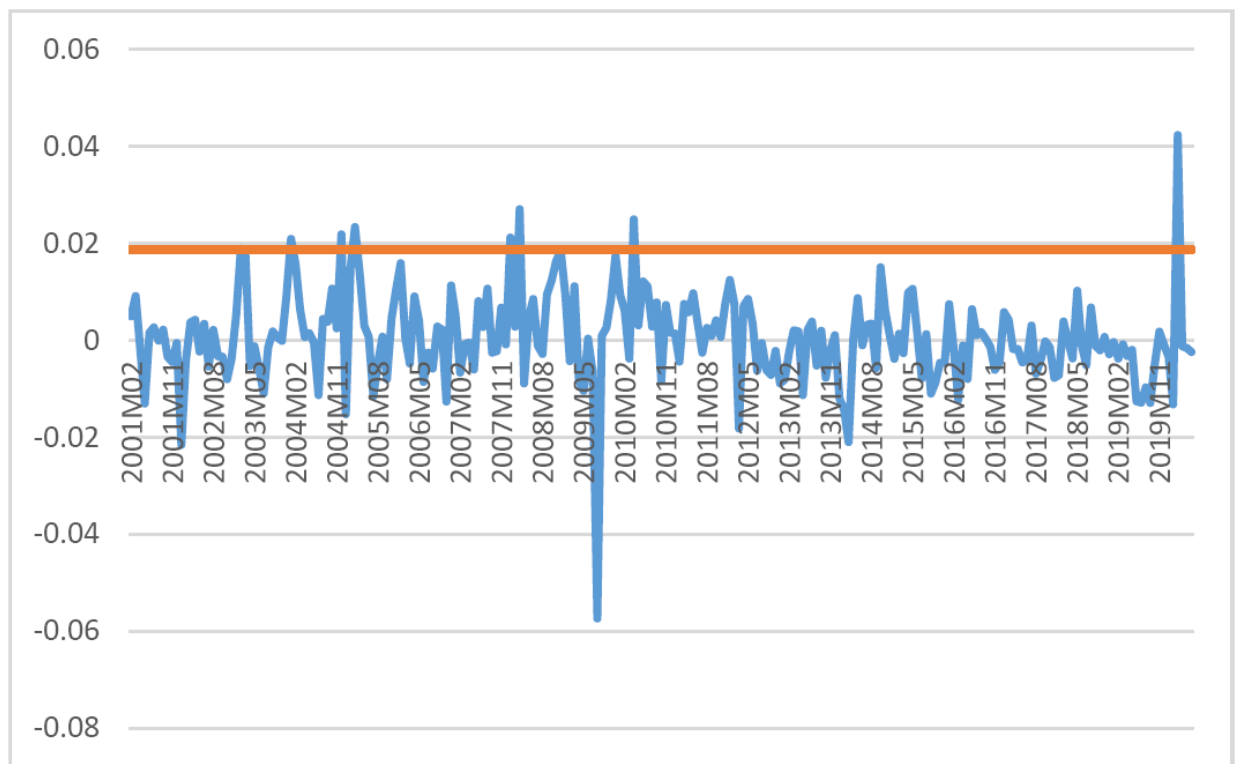

Note: Orange horizontal line is 1.5 standard deviation crisis threshold level.

Source: Authors' own calculations.

In Figure 5, we can observe the ISP on Italian market for the euro era. One can see some periods of significant pressure but the most distinct one occurred in May 2018. This time it can be explained by a rapid growth in Italian interest 
rates raising parallel the risk premium for Italy. This growth fueled fears of higher interest expenditure of Italian government: "The increase in the spot yields at issuance in 2018 (and in early 2019) reflects higher risk premium on Italy's public debt, with sovereign spreads undergoing an upward level shift in the order of around 100 basis points since May 2018. As such, compared to the projections in the Commission 2018 spring forecast, interest expenditure in 2018 turned out higher by around EUR 2.2 billion (at EUR 65 billion instead of 62.8 billion)." (European Commission, 2019).

Figure 5. Index of speculative pressure; Italy 1999-2020

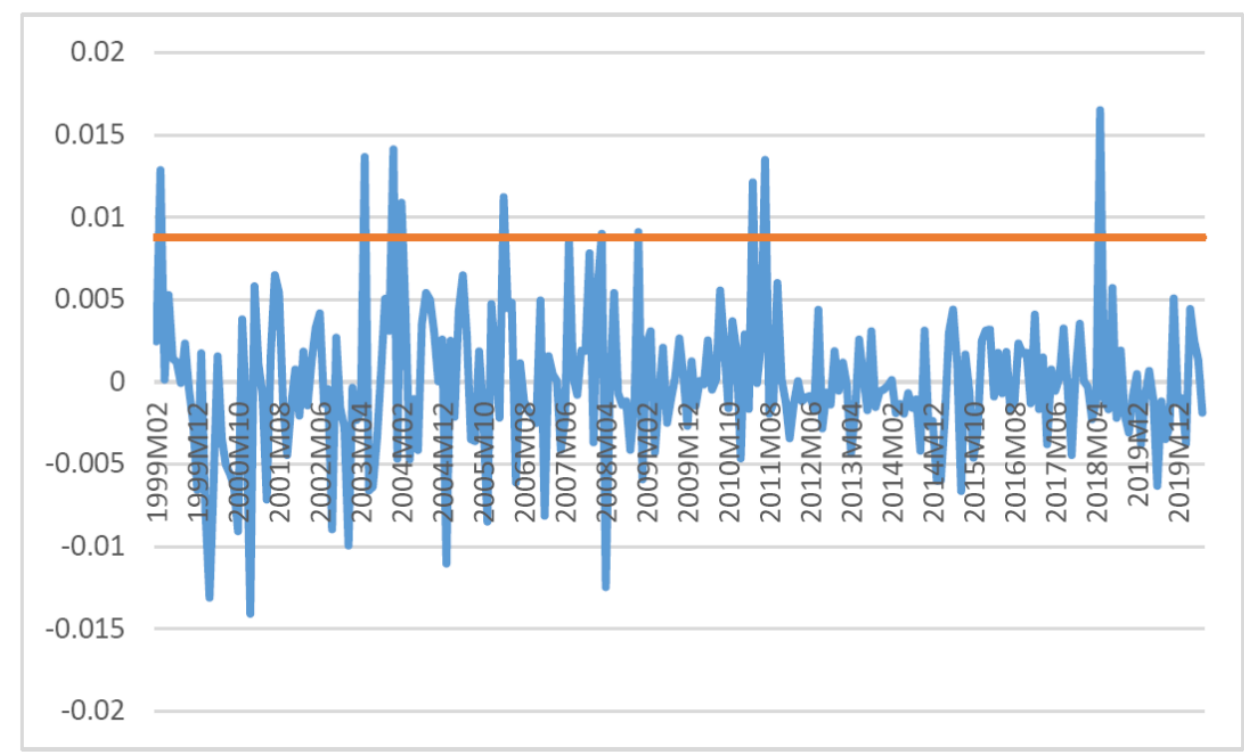

Note: Orange horizontal line is 1,5 standard deviation (crisis threshold level).

Source: Authors' own calculations.

After the decomposition of the last two indexes (10) and (11) using weights from two first formulas (8) and (9) we obtained shadow exchange rates for EUR/GRD and EUR/ITL.

Figure 6 shows the nominal EUR/GRD exchange rate in 1989-2000 and shadow exchange rate in January 2001 - May 2020. The parity exchange rate was fixed at EUR/GRD 340.76. As can be seen, the shadow exchange rate, after the introduction of the euro, was appreciating for the first three years, and stabilized until 2008, to reach the level of almost GRD 1.400 per EUR during the global financial crisis. 
Figure 6. Greece. Nominal rate EUR/GRD (January 1989 - December 2000), shadow exchange rate EUR/GRD and euro parity (January 2001 - May 2020)

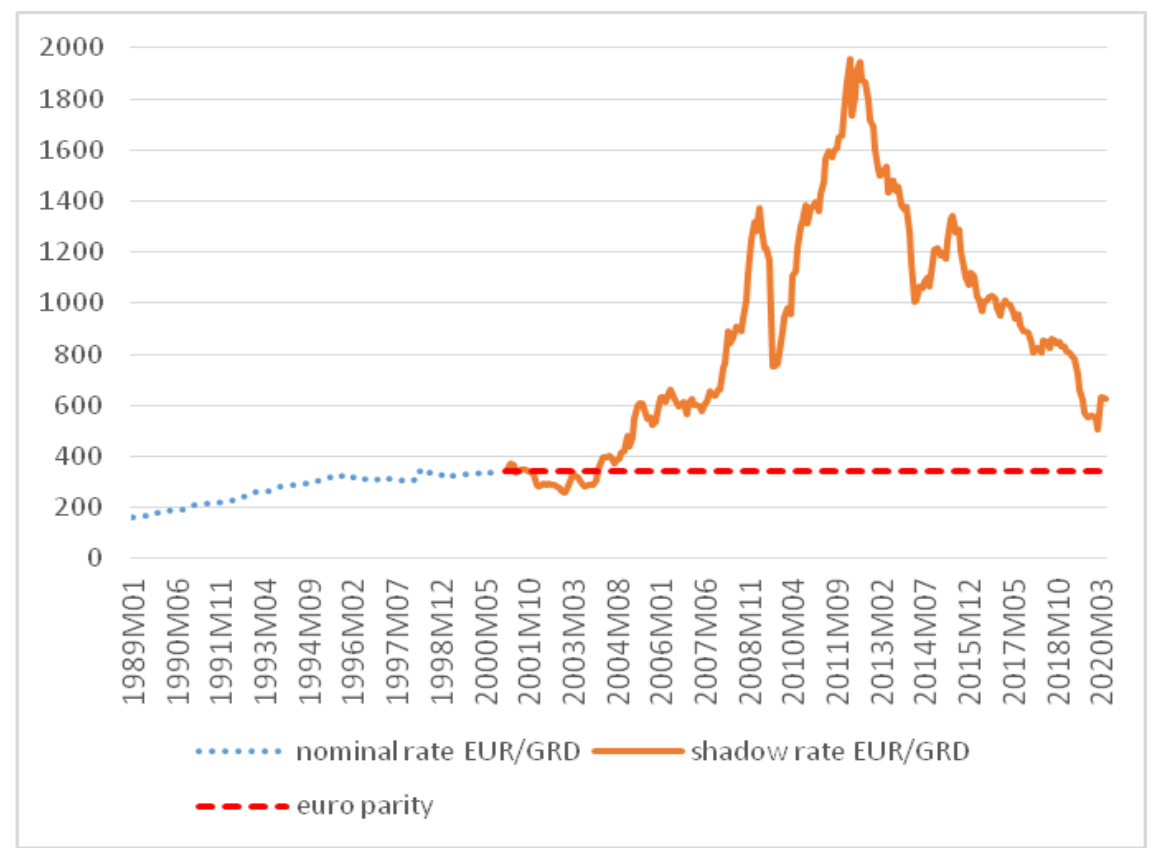

Source: Authors' own calculations.

However, the peak of the shadow drachma depreciation was yet to come. In 2011-2012 the shadow exchange rate reached almost GRD 2.000 per EUR. What would that mean in practice? If in the second half of 2011 Greece had left the euro area and introduced new currency at the euro parity, it would have been expected that in a result of bank runs and banking and debt crisis, the new currency would immediately lose over $80 \%$ of its value. This would cause an immediate collapse of imports and economic paralysis.

The following years brought a calming down of the market situation and an appreciation of the shadow exchange rate. It should be emphasized that the aid and stabilization plans have been apparently successful, at least in this aspect. If Greece is planning or is forced to leave the euro zone now, it would be on much better terms than in 2011-2012. Of course, the potential scale of the shock depreciation of the new-old currency would still be significant (up to around GRD 600 per EUR), but perhaps not so destructive and would take place in a much better macroeconomic environment and with a balanced budget. We can also see that pandemic crisis slightly reverted this positive trend and shadow rate started to weaken last months. 
Figure 7. Italy. Nominal rate EUR/ITL (January 1989 - December 1998), shadow exchange rate EUR/ITL and euro parity (January 1999 - June 2020)

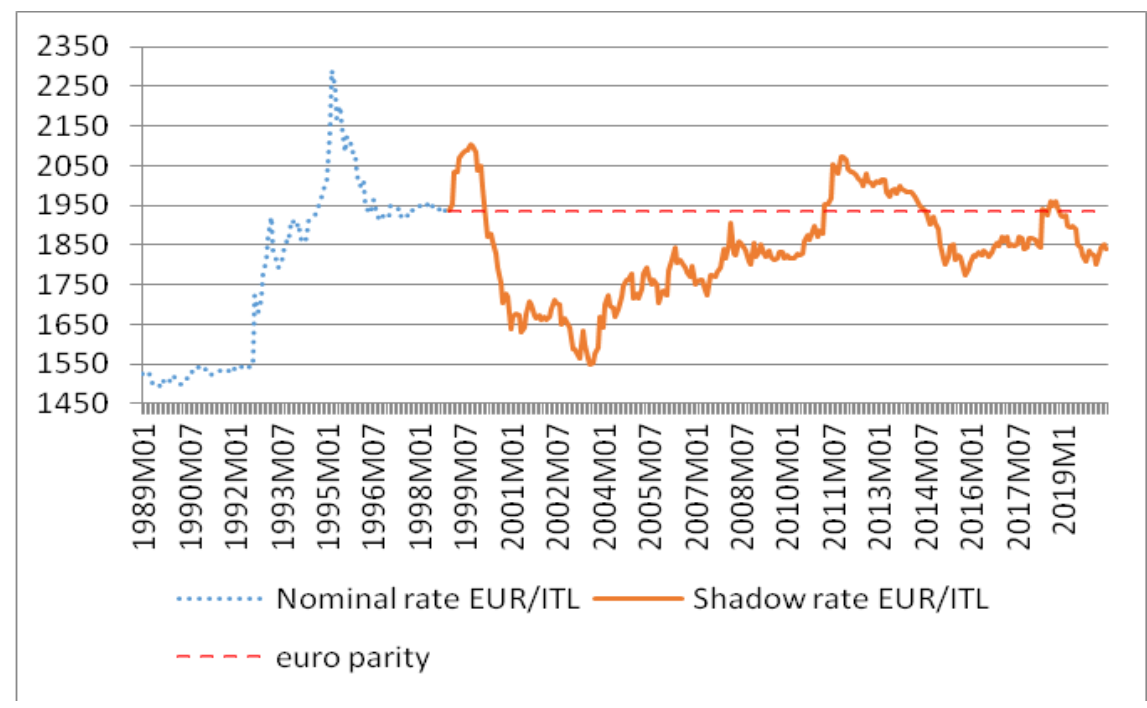

Source: Authors' own calculations.

Figure 7 shows the nominal EUR/ITL exchange rate 1989-1998 and the shadow exchange rate in January 1999 - June 2019 (the parity exchange rate was set at EUR/ITL 1936.27). One can see that before the introduction of the euro, the lira was very volatile. During participation in ERM I, in 1992-1994, Italian currency was subject to a very strong speculation, and the market calmed down only three years after widening the fluctuation band for the lira from $+/-6 \%$ to $+/-15 \%$. It is more than obvious that the introduction of the euro in Italy stabilized the situation on the currency market and allowed long-term planning of economic activity.

Analyzing behavior of shadow exchange rate, it can be noticed that this rate weakened only in the first year after the euro introduction (and also during the crisis in 2011 and, to a lesser extent, in the second half of 2018). Throughout the entire period of participation in the euro area the shadow rate was relatively stable and overvalued. This means that the past of the lira (recognized by markets as a weaker currency) was quickly forgotten, and Italy apparently benefited greatly from the good reputation of the euro. A significant benefit was a high correlation of Italian interest rates (e.g., yields on government bonds) with German ones. 
Most importantly, membership in the euro area was a success of Italian monetary authorities. During this period, they managed to accumulate significant foreign exchange reserves (increasing from USD 19 billion in January 1999 to USD 43 billion in March 2020). The decisive factor of stability and strength of the 'new lira' would be huge (2451 tons) Italian gold reserves worth USD 150 billion, which give Italy the third place in the world (behind the United States and Germany). ${ }^{4}$ It seems that Italy would be well prepared for a possible exit from the monetary union. Moreover, this step does not seem to have a significant impact on competitiveness of the Italian economy. According to the shadow exchange rate concept, the 'new lira' would have a similar rate (ITL 1850/EUR) to the current parity (ITL 1936.27/EUR). Surprisingly, the pandemic crisis had no negative impact on the shadow exchange rate (which is based on macroeconomic fundamentals as in equation (2)). After thousands of casualties and destruction of local economies we should expect banking crisis, bankruptcy of a state resulting, i.a., in loss of foreign exchange reserves and growth of Italian interest rates. Unexpectedly, it did not happen, as can be seen in Figure 7.

\section{Discussion}

It is understandable that the methodology used in this research has some weaknesses. We are aware of the fundamental changes in the financial market in the last four decades. The number of market participants is much greater, new financial instruments were introduced. Unusual quantitative easing (QE) programs and negative interest rates virtually destroyed the informative value of money and bonds markets. The international economy witnessed many currency, financial, and debt crises. Moreover, a large number of key currencies disappeared after the introduction of the euro. The significance and credibility of the others, making up foreign exchange reserves in many economies, fell drastically.

The advantage of this methodology is quite a long historical perspective. About twenty years of estimation of index of speculative pressure should give quite reliable values of weights on components of the index. The authors think that the original aspect of this research was merging two important economic concepts of shadow exchange rate and the index of speculative pressure. The results can help in discussions about consequences of leaving the euro zone.

4 Gold reserves of Greece are 113 tons, approximately 11 tons per 1 million population, comparing to Italian over 40 tons per 1 million. 
Couharde et al. (2017) assessed the sustainability of current account imbalances in the euro area calculating real exchange misalignments, i.e., the differences between the observed real exchange rates and their equilibrium levels. They found that in 2000-2008 Greek drachma and Italian lira over-appreciated approximately by $22 \%$ and $16 \%$, respectively, in 2008-2016 (after the financial crisis of 2008 that triggered the trend reversal) over-depreciated by $11.9 \%$ and $15.3 \%$, respectively. However, Couharde et al. (2017) stated that Italian currency was undervalued by $2.3 \%$ while Greek currency overvalued by $5.7 \%$.

Although we tried to evaluate nominal rates (not real ones) one can see that the potential deviation of the Italian currency from the current value of the euro (either nominal or real values) is rather insignificant, and estimates of REER or BEER should support expectations of financial market participants. However, the real overvaluation of the Greek currency is quite understandable due to economic, financial, and political weaknesses, but we think that nominal depreciation after potential Grexit would be higher, even up to $75 \%$, if leaving the euro zone occurs at the fixing rate.

Of course, another riddle is the process of exiting the euro zone itself. We can imagine either the introduction of old national currencies (drachmas and liras) or introduction of new currencies (e.g., south euros). New parity for translation of debts and obligations (at least) is unknown. We can imagine that the rate of a new currency will be floating at once, creating additional factor of chaos but creating new opportunities for speculation.

\section{Conclusions}

The economic, political, and social shocks that had hit the European Union and the euro area in the last decade stimulated discussions of the possible withdrawal of Greece and Italy from the common currency area. The key issue of Grexit and Italexit would be exchange rates of new currencies and the scale of potential depreciations. The economic literature usually takes into account real exchange rates and potential trade effects (Couharde et al., 2017) but the analysis of nominal rates can open the discussion about the effects of the exit on financial markets and individual decisions of market participants (i.e., entrepreneurs, households).

The aim of this study was to estimate the EUR/GRD and EUR/ITL nominal exchange rates after the Grexit and Italexit using original concept of merging two economic ideas of shadow exchange rate (Piersanti, 2012) and the index of speculative pressure (Eichengreen et al., 1994). 
Initially, we expected that Grexit and Italexit would lead to sudden and sharp depreciation of new currencies. In the case of Greece, we cannot reject this hypothesis because our survey suggests that the new currency would depreciate by $75 \%$ in respect to the current parity (or should be issued with an appropriate discount). ${ }^{5} \mathrm{In}$ the case of Italy, we have to reject the hypothesis. It was expected that ongoing deindustrialization, potential banking crisis, supply-side bottlenecks, deterioration of loan quality (Bagnai et al., 2017, p. 530) should frighten financial investors heavily enough. However, our research shows that the difference between the current euro parity and shadow exchange rate is quite small (with expected nominal appreciation by 5\%). That suggests that Italexit would not bring devastating consequences neither for a new currency nor for Italian financial market. This surprising result can be probably explained by the difference in economic potentials between these two countries and substantial gold reserves accumulated by Italy.

The last question is practical application of the above results of the research. If Greek authorities decide to convert old debts and receivables at the rate $1 \mathrm{EUR}=1$ Greek euro (or $1 \mathrm{EUR}=340.75 \mathrm{GRD}$ ) the projected exchange rate in the free market will potentially go to 1 EUR $=1.75$ Greek euro (or EUR/600 GRD). Probably, Greek citizens will try to hoard old, European euros and put in circulation new, Greek euros. In the Italian case, we can believe that the rate of a new currency will remain at the parity, 1 EUR $=1$ Italian euro (or 1 EUR $=1936.27$ ITL) if the government manages to avoid a banking crisis. Foreign exchange and gold reserves will probably calm the market and mitigate the speculation against a new Italian currency.

We are afraid that similar research in the future will be extremely difficult, if not impossible. After vanishing of national currencies nominal interest rates are currently under unprecedented official control. All market pressure will probably shift itself to foreign exchange reserves - including gold.

\section{References}

Athanassiou, P. (2009). Withdrawal and expulsion from the EU and EMU (ECB Legal Working Paper, No. 10). Frankfurt am Main: European Central Bank.

Bagnai, A., Granville, B., \& Mongeau Ospina, C.-A. (2017, August). Withdrawal of Italy from the euro area: Stochastic simulations of a structural macroeconometric model. Economic Modelling, 64, 524-538. https://doi.org/10.1016/j.econmod.2017.04.010

5 This value is well above the thresholds proposed by Frankel \& Rose (1996) or Osband \& Van Rijckeghem (2000) - both for annual and monthly data. 
BBC. (2015, June 24). Would Greece be better off outside the euro zone? Retrieved from www.bbc.com/news/world-europe-33084508

Buiter, W., \& Rahbari, E. (2012). Global economics view. Rising risks of Greek euro area exit. Citigroup Global Markets. Retrieved from https://willembuiter.com/grexit.pdf

Cepiku, D. (2018), Public administration characteristics and performance in EU28: Italy. Brussels: European Commission. Retrieved from https://ec.europa.eu/social/ BlobServlet?docId=19956\&langId=pt

Di Quirico, R. (2010). Italy and the global economic crisis. Bulletin of Italian Politics, 2(2), 3-19. Retrieved from https://www.gla.ac.uk/media/media_191024_en.pdf

Couharde, C., Delatte, A.-L., Grekou, C., Mignon, V., \& Morvillier, F. (2017, March). Sur- et sous-évaluations de change en zone euro: vers une correction soutenable des déséquilibres? La Lettre du CEPII, 375. Retrieved from http://www.cepii.fr/PDF_ PUB/lettre/2017/let375.pdf

Ehnts, D., \& Paetz, M. (2021). COVID-19 and its economic consequences for the Euro Area. Eurasian Economic Review, 11, 227-249. https://doi.org/10.1007/s40822020-00159-w

Eichengreen, B., Rose, A., \& Wyplosz, C. (1994). Speculative attacks on pegged exchange rates: An empirical exploration with special reference to the European Monetary System (NBER Working Paper, No. 4898). Cambridge, MA: National Bureau of Economic Research. https://doi.org/10.3386/w4898

European Central Bank. (2019a). Annual accounts of the ECB. Frankfurt am Main: European Central Bank. Retrieved from https://www.ecb.europa.eu/pub/annual/annual -accounts/html/index.en.html

European Central Bank. (2019b). Annual report of the ECB. Frankfurt am Main: European Central Bank. Retrieved from https://www.ecb.europa.eu/pub/annual/html/ index.en.html

European Commission. (2019). Report from the Commission. Italy. Report prepared in accordance with Article 126(3) of the Treaty on the Functioning of the European Union. Brussels, 5.6.2019 $\operatorname{COM(2019)~532.~Retrieved~from~https://ec.europa.eu~}$ /info/sites/info/files/economy-finance/com2019_532_it_en.pdf

Eurostat. (2020a). Database. Retrieved from https://ec.europa.eu/eurostat/web/ government-finance-statistics/data/database

Eurostat. (2020b). General government deficit/surplus. Retrieved from https://ec.europa. eu/eurostat/databrowser/view/tec00127/default/table?lang=en

Eurostat. (2020c). Real GDP growth rate - volume. Retrieved from https://ec.europa. eu/eurostat/web/products-datasets/-/tec00115\&lang=en

Flood, R. P., \& Garber, P. M. (1984). Collapsing exchange-rate regimes. Some linear examples. Journal of International Economics, 17(1-2), 1-13. https://doi.org/ 10.1016/0022-1996(84)90002-3 
Frankel, J., \& Rose, A. (1996). Currency crashes in emerging markets: Empirical indicators (NBER Working Paper, No. 5437). Cambridge. MA: National Bureau of Economic Research. https://doi.org/10.3386/w5437

Frieden, J., \& Walter, S. (2017). Understanding the political economy of the eurozone crisis. Annual Review of Political Science, 20. 371-390. https://doi.org/10.1146/ annurev-polisci-051215-023101

Gavin, J. (2017, September 8). Italy's dual currency schemes may be long road to euro exit. Retrieved from https://www.reuters.com/article/us-italy-euro-analysis/italysdual-currency-schemes-may-be-long-road-to-euro-exit-idUSKCN1BJ20F

Girton, L., \& Roper, D. (1976). A monetary model of exchange market pressure applied to post-war Canadian experience (International Finance Discussion Papers, No. 92). Washington, D.C.: Federal Reserve System. https://doi.org/10.17016/ifdp.1976.92

Goulard, S. (2020). The impact of the US-China trade war on the European Union. Global Journal of Emerging Market Economies, 12(1) 56-68. https://doi.org/ $10.1177 / 0974910119896642$

IMF. (2018). International Financial Statistics. DVD-ROM Database. Washington, D.C.: International Monetary Fund.

IMF. (2020). Macroeconomic and financial data. Retrieved from https://data.imf.org/?sk =388dfa60-1d26-4ade-b505-a05a558d9a42

Kaminsky, G. L. (2006). Currency crises: Are they all the same? Journal of International Money and Finance, 25(3), 503-527. https://doi.org/10.1016/j.jimonfin.2006.01. 002

Katsinos, A., \& Mariolis, T. (2012). Switch to devalued drachma and cost-push inflation: A simple input-output approach to the Greek case. Modern Economy, 3(2), 164-170. https://doi.org/10.4236/me.2012.32023

Kibritçioğlu, A. (2002, June 24). Excessive risk-taking, banking sector fragility and banking crises (College of Commerce and Business Administration Working Papers, No. 02-0114). Urbana-Champaign, IL.: University of Illinois. https://doi.org/ $10.2139 /$ ssrn.317491

Krugman, P. (1979, August). A model of balance-of-payments crises. Journal of Money, Credit and Banking, 11(3), 311-325. https://doi.org/10.2307/1991793

Lagman-Martin, A. (2004). Shadow exchange rates for project economic analysis: Toward improving practice at the Asian Development Bank (ERD Technical Note Series, No. 11). Manila: Asian Development Bank. Retrieved from https://www.adb. org/sites/default/files/publication/29856/tn-11-shadow-exchange-rates.pdf

Mariolis, T. (2013). Currency devaluation, external finance and economic growth: A note on the Greek case. Social Cohesion and Development, 8(1), 59-64. https:// doi.org/10.12681/scad.9089

Marion, N. P., \& Flood, R. P. (1998). Perspectives on the recent currency crisis literature (IMF Working Paper, No. 98). Washington, D.C.: International Monetary Fund. https://doi.org/10.5089/9781451855166.001 
Martin, A. (2020, July 20). Soaring eurozone government debt reignites call for cancellation. The Nation. Retrieved from https://www.thenation.com/article/should-greeceleave-the-euro/

Medalla, E. M., \& Power, J. H. (1984). Estimating the shadow exchange rate, the shadow wage rate and the social rate of discount for the Philippines (PIDS Staff Paper, No. 8403). Manila: PIDS.

Mayer, T. (2012, May 23). Der Geuro: Eine Parallelwährung für Griechenland? (DB Research). Frankfurt am Main: Deutsche Bank AG. Retrieved from https://www. dbresearch.de/PROD/RPS_DE-PROD/PROD0000000000465357/Der_Geuro\%3

A_Eine_Parallelw\%C3\%A4hrung_f\%C3\%BCr_Griechenland\%3F.PDF

Osband, K., \& Van Rijckeghem, C. (2000). Safety from currency crashes. IMF Staff Papers, 47, 238-258. https://doi.org/10.2307/3867660

Piersanti, G. (2012). The macroeconomic theory of exchange rate crises. Oxford: Oxford University Press.

Provopoulos, G. (2010). The Greek economic crisis and the euro (BIS Review, No. 87). Basel: BIS. Retrieved from https://www.bis.org/review/r100624d.pdf

Scharpf, F. (2017). The southern euro. Retrieved from www.ips-journal.eu/topics/ european-union/article/show/the-southern-euro-2483/

Shor, R. (2015). What is the potential impact of a "grexit"? FXCM. Retrieved from https://www.fxcm.com/markets/insights/what-is-the-potential-impact-of-a-grexit/

Thanki, A. (2015, July 20). Should Greece leave the euro? The Nation. Retrieved from www.thenation.com/article/should-greece-leave-the-euro/

Tsakok, I. (1990). Agricultural price policy: A practitioner's guide to partialequilibrium analysis. Ithaca, NJ: Cornell University Press.

Ural, M., \& Balaylar, N. A. (2007). Bankacılık Sektöründe Yüksek Risk Alımı ve Baskı İndeksleri. Finans Politik \& Ekonomik Yorumlar, 44(509), 47-56. Retrieved from http://www.ekonomikyorumlar.com.tr/files/articles/15282000395_4.pdf

Die Welt. (2016, December 1). Berlusconi fordert eine zweite Währung für Italien. Retrieved from https://www.welt.de/politik/ausland/article159887127/Berlusconifordert-eine-zweite-Waehrung-fuer-Italien.html

Wolinsky, J. (2011, May 11). Should Greece abandon the euro? Retrieved from www. gurufocus.com/news/132641/should-greece-abandon-the-euro 